\title{
BADANIE CHARAKTERYSTYK DYNAMICZNYCH PODWIESZONEJ KŁADKI DLA PIESZYCH WYKONANEJ Z KOMPOZYTU GFRP
}

\begin{abstract}
W artykule przedstawiono sposób określenia i wyniki analizy charakterystyk dynamicznych podwieszonej kładki dla pieszych, znajdującej się w miejscowości Kolding w Danii, wykonanej w całości z kompozytu polimerowego na bazie włókien szklanych GFRP. Na podstawie pomiarów przyspieszeń drgań swobodnych pomostu kładki, wymuszonych podskokami jednej osoby, dokonano identyfikacji pięciu pierwszych częstości drgań własnych, odpowiadających postaci drgań własnych i wartości liczby tłumienia konstrukcyjnego. Częstości i postacie drgań własnych wyznaczono metodą dekompozycji w dziedzinie częstotliwości. Wartości liczby tłumienia konstrukcyjnego wyznaczono na podstawie aproksymacji metodą najmniejszych kwadratów odfiltrowanych drgań swobodnych pomostu kładki. Otrzymane wartości liczby tłumienia porównano $\mathrm{z}$ wartościami podanymi w literaturze dla wybranych kładek o konstrukcjach wykonanych z innych, alternatywnych materiałów. Stwierdzono stosunkowo dużą wartość tłumienia konstrukcyjnego analizowanej kładki. Otrzymane wyniki badań mogą być pomocne do obliczenia dynamicznej odpowiedzi nowoprojektowanych konstrukcji mostowych, a także do oceny i monitorowania stanu technicznego istniejących obiektów mostowych o konstrukcji wykonanej z kompozytów na bazie włókien szklanych GFRP.
\end{abstract}

Słowa kluczowe: obiekt mostowy, kompozyt GFRP, parametry modalne, drgania swobodne, thumienie konstrukcyjne

\section{Wprowadzenie}

Kompozyty polimerowe na bazie włókien szklanych GFRP (Glass Fiber Reinforced Polymer) należą do materiałów innowacyjnych, stopniowo wdraża-

\footnotetext{
${ }^{1}$ Autor do korespondencji / corresponding author: Piotr Górski, Politechnika Opolska, Wydział Budownictwa i Architektury, ul. Katowicka 48, 45-061 Opole, tel.: +48 77 4498588, e-mail: p.gorski@po.opole.pl

2 Beata Stankiewicz, Politechnika Opolska, Wydział Budownictwa i Architektury, ul. Katowicka 48, 45-061 Opole, tel.: +48 77 4498587, b.stankiewicz@ po.opole.pl

${ }_{3}$ Marcin Tatara, Politechnika Opolska, Wydział Budownictwa i Architektury, ul. Katowicka 48, 45-061 Opole, tel.: +48 77 4498592, m.tatara@ po.opole.pl
} 
nych w obiektach mostowych jako materiał konstrukcyjny. Przemawia za tym szereg zalet tego materiału, do których można zaliczyć: stosunkowo dużą wytrzymałość na zginanie, mały ciężar własny, łatwość montażu, wysoką odporność na działanie czynników atmosferycznych, a także łatwość kształtowania elementów. Pomimo wielu zalet kompozyty polimerowe GFRP mają pewne ograniczenia. Należą do nich: stosunkowo mała wartość modułu sprężystości podłużnej, mała odporność alkaliczna i mała odporność na pękanie [11]. Z tego względu w dalszym ciągu prowadzone są badania w celu poprawy własności mechanicznych i trwałości tego materiału, np. [12].

Obecnie kompozyty polimerowe GFRP stosowane są w konstrukcjach obiektów mostowych zwykle w połączeniu z innymi powszechnie stosowanymi materiałami konstrukcyjnymi, do których należą stal i beton. W nowoczesnych konstrukcjach kładek dla pieszych kompozyty na bazie włókien szklanych często stosowane są jako materiał płyt pomostowych. Przykłady takich zastosowań przedstawiono w pracy [11]. Obiekty mostowe o konstrukcji wykonanej w całości z kompozytu na bazie włókien szklanych GFRP wciąż należą do nielicznych. $\mathrm{Na}$ świecie znanych jest zaledwie kilka takich konstrukcji. Wśród nich można wymienić: kładkę dla pieszych Scripps Bridge, La Jolla, USA [4], kładkę Aberfeldy Bridge, Szkocja, Wielka Brytania [10], kładkę Pontresina Bridge, Szwajcaria (rys. 1a) [6], kładkę w pobliżu miasta Lleida, Hiszpania (rys. 1b) [5], kładkę w miejscowości Tainan, Taiwan [7] i kładkę w miejscowości Kolding, Dania [5], która jest przedmiotem badań przedstawionych $\mathrm{w}$ niniejszym artykule. Z krajowych realizacji należy wymienić pierwszy drogowy most kompozytowy w Polsce, oddany do użytku w 2016r. w miejscowości Błażowa koło Rzeszowa. Znane są także badania prototypowego mostu pieszo-rowerowego o konstrukcji z kompozytu przekładkowego, znajdującego się na terenie kampusu Politechniki Gdańskiej [9].

a)

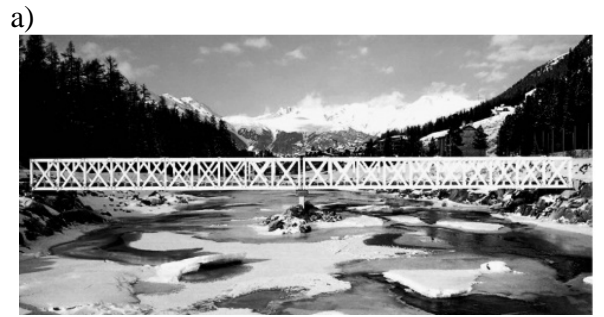

b)

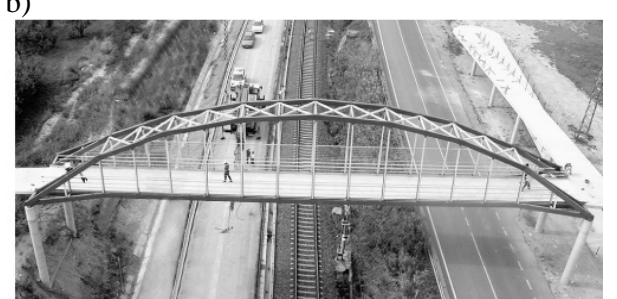

Rys. 1. Kładki kompozytowe: a) Pontresina Bridge, Szwajcaria, b) Lleida, Hiszpania, na podstawie $[5,6]$

Fig. 1. Composite footbridges: a) Pontresina Bridge, Switzerland, b) Lleida, Spain, based on $[5,6]$

Podstawowymi charakterystykami modalnymi konstrukcji inżynierskich są częstości drgań własnych, odpowiadające im postacie drgań własnych i tłumienie konstrukcyjne. Znajomość wartości rzeczywistych charakterystyk stanowi podstawę weryfikacji poprawności rozwiązań przyjętych na etapie projektowa- 
nia konstrukcji i może być pomocna do oceny i monitorowania stanu technicznego konstrukcji poddanych działaniom obciążeń dynamicznych. Jest to szczególnie istotne $\mathrm{w}$ odniesieniu do tłumienia konstrukcyjnego, które jest jednym z ważniejszych, a jednocześnie niepewnym parametrem, znacząco redukującym niepewność obliczeniowej odpowiedzi konstrukcji. Wiarygodnym sposobem określenia rzeczywistych wartości charakterystyk dynamicznych konstrukcji jest wykonanie pomiarów ich drgań. Publikacje dotyczące badania charakterystyk dynamicznych i odpowiedzi pod obciążeniem dynamicznym obiektów mostowych o konstrukcji wykonanej z kompozytów polimerowych na bazie włókien szklanych GFRP są wciąż nieliczne i niewystarczające do sformułowania wytycznych i zaleceń do projektowania tego typu obiektów. Dlatego obecnie istnieje duża potrzeba wykonania takich badań.

W artykule przedstawiono sposób określenia i wyniki analizy charakterystyk dynamicznych podwieszonej kładki dla pieszych, znajdującej się w miejscowości Kolding w Danii, wykonanej w całości z kompozytu polimerowego na bazie włókien szklanych GFRP. Na podstawie pomiarów przyspieszeń drgań swobodnych pomostu kładki, wymuszonych podskokami jednej osoby, dokonano identyfikacji pięciu pierwszych częstości drgań własnych, odpowiadających postaci drgań własnych i wartości liczby tłumienia konstrukcyjnego. Częstości i postacie drgań własnych wyznaczono metodą dekompozycji w dziedzinie częstotliwości. Wartości liczby tłumienia konstrukcyjnego wyznaczono na podstawie aproksymacji metodą najmniejszych kwadratów odfiltrowanych drgań swobodnych pomostu kładki. Otrzymane wartości liczby tłumienia porównano $\mathrm{z}$ wartościami podanymi w literaturze dla wybranych kładek o konstrukcjach wykonanych z innych, powszechnie stosowanych materiałów. Stwierdzono stosunkowo dużą wartość tłumienia konstrukcyjnego analizowanej kładki. Otrzymane wyniki badań mogą być pomocne do przewidywania dynamicznej odpowiedzi nowoprojektowanych konstrukcji mostowych, a także do oceny i monitorowania stanu technicznego istniejących obiektów mostowych o konstrukcji wykonanej z kompozytów na bazie włókien szklanych GFRP.

\section{Kładka dla pieszych, zestaw pomiarowy i wyniki pomiarów}

Obiektem badań jest podwieszona kładka dla pieszych w całości (łącznie z pylonem i odciągami) wykonana z kompozytu GFRP, znajdująca się w miejscowości Kolding w Danii nad jedną z głównych linii kolejowych prowadzących do centrum miasta. Kładka została wykonana jako dwuprzęsłowa z pomostem podwieszonym do pylonu w kształcie litery A. Całkowita długość pomostu wynosi 40,77 m, zaś jego szerokość użytkowa 3,21 m. Rozpiętości teoretyczne przęseł pomiędzy osiami podpór wynoszą 26,35 m i 12,40 m. Dźwigary nośne przęseł wykonane zostały w postaci belek z perforowanych profili modułowych o wysokości $1,5 \mathrm{~m}$, długości $3,1 \mathrm{~m}$ i grubości $12 \mathrm{~mm}$, połączonych ze sobą za pomocą śrub. Dźwigary podwieszono do pylonu o całkowitej wysokości 
17,61 m za pośrednictwem 4 par odciągów, wykonanych z kwadratowych, zamkniętych profili kompozytowych o długościach 17,85 m, 17,66 m, 13,58 m i 13,36 m. Wymiary zewnętrzne pylonu w płaszczyźnie poziomej są zmienne po wysokości i wynoszą od 5,22 m x 1,29 m (u podstawy) do $1,39 \mathrm{~m}$ x $0,49 \mathrm{~m}$ (w wierzchołku pylonu). Widoki ogólne analizowanej kładki przedstawiono na rys. 2, zaś jej przekrój poprzeczny i podłużny na rys. 3 .

a)

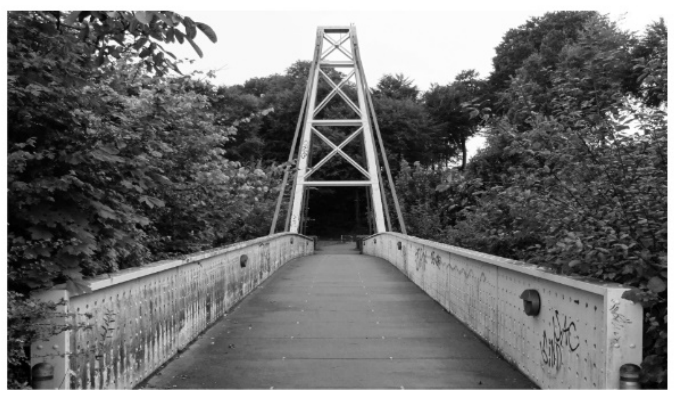

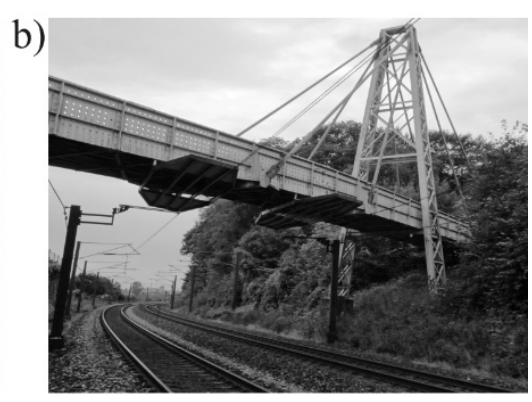

Rys. 2. Kładka dla pieszych w Kolding, Dania: a) widok na pomost i b) widok z boku

Fig. 2. Footbridge in Kolding, Denmark: a) the view on the deck and b) the side view

a)

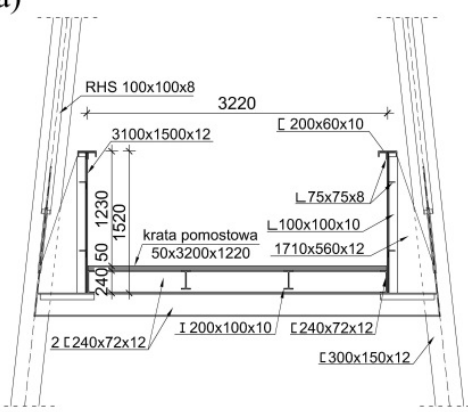

b)

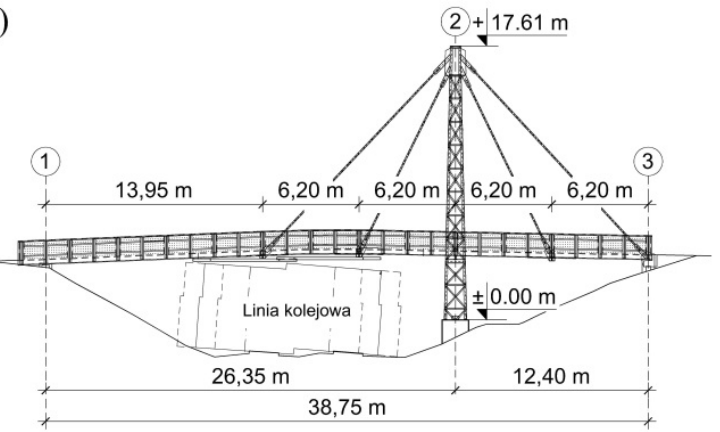

Rys. 3. Kładka dla pieszych w Kolding, Dania: a) przekrój poprzeczny i b) podłużny

Fig. 3. Footbridge in Kolding, Denmark: a) the cross-section and b) the longitudinal section

Pomiary drgań swobodnych kładki wykonano w dniu 1.10.2016r. Do pomiarów zastosowano dwa niskoszumowe czujniki typu PCB 3711E112G, wykonane w technologii Micro-Electro-Mechanical System (MEMS), które mają zdolność rejestracji przyspieszeń drgań o częstościach w przedziale od 0 do $400 \mathrm{~Hz}$ w zakresie pomiarowym $\pm 2 \mathrm{~g}$. Czujniki przyspieszeń były połączone z kartą pomiarową typu Data Translation DT9837A, a ta z kolei z komputerem typu Laptop, służącym do stałej kontroli i zapisu danych w trakcie prowadzonych badań. Do określenia postaci drgań konieczne było zastosowanie dwóch czujników jednocześnie. W tym celu wybrano 28 punktów pomiarowych znaj- 
dujących się w górnej części dźwigarów nośnych przęseł kładki (dźwigar „A” i „B”), głównie w odstępach co 3,1 m wzdłuż osi podłużnej dźwigarów. W czasie badań jeden z czujników znajdował się w stałym położeniu w punkcie referencyjnym, zaś drugi był umieszczany kolejno od punktu 1 do punktu 27. Lokalizację punktów pomiarowych przedstawiono na rys. 4. Po każdej zmianie położenia czujnika ruchomego wykonywane były pomiary drgań swobodnych pomostu kładki w płaszczyźnie pionowej, w czasie co najmniej 15 sekund, wymuszonych pojedynczym podskokiem jednej osoby. Podskoki wykonywane były na środku pomostu w pobliżu punktu referencyjnego. Pomiary rejestrowano z częstością próbkowania $200 \mathrm{~Hz}$.

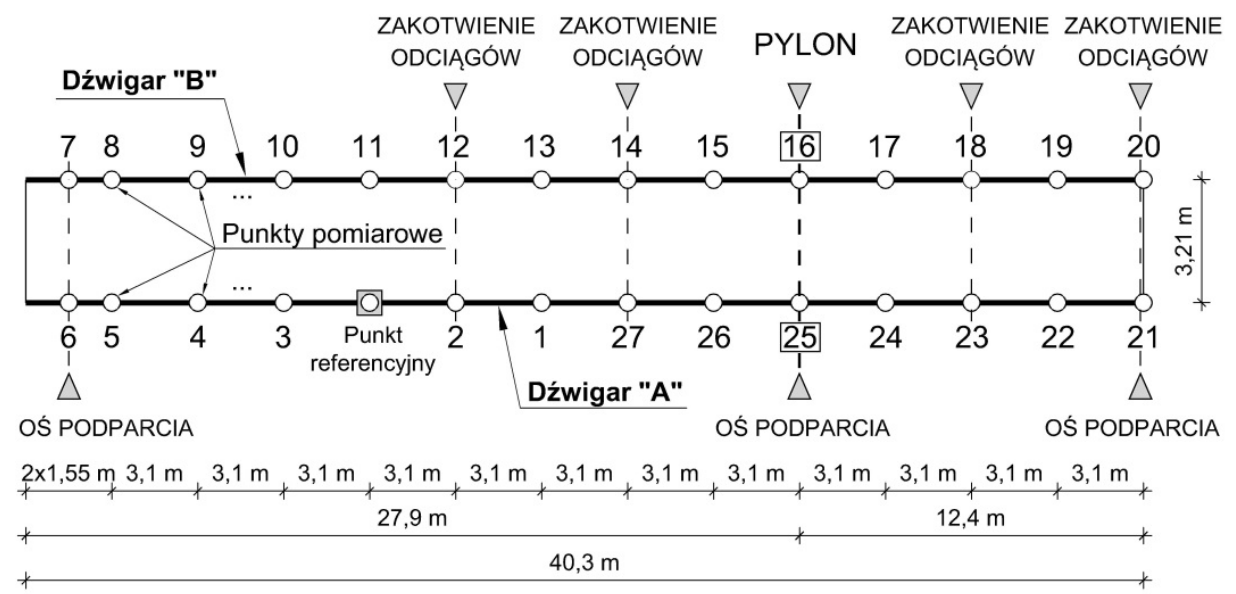

Rys. 4. Lokalizacja punktów pomiarowych na dźwigarach kładki dla pieszych

Fig. 4. Locations of the measuring points on the girders of the footbridge

Na rys. 5a przedstawiono przykładowe zarejestrowane dwie serie przyspieszeń drgań swobodnych dźwigara „A” w płaszczyźnie pionowej w punkcie referencyjnym i w punkcie pomiarowym nr 23 wymuszonych podskokiem jednej osoby. Na podstawie pomierzonych przyspieszeń drgań pomostu określono, za pomocą szybkiej transformacji Fouriera, częstości drgań swobodnych pomostu, które na osi odciętych odpowiadały wartościom dominującym w uzyskanym spektrum. Wykresy funkcji gęstości widmowej mocy zarejestrowanych przyspieszeń drgań pionowych dźwigara „A” w punkcie referencyjnym i w punkcie pomiarowym nr 23 przedstawiono na rys. 5b. Na otrzymanym spektrum widocznych jest pięć wyraźnych pików, których wartości odpowiadają pięciu pierwszym częstościom drgań swobodnych pomostu, tj.: $f_{1}=4,30 \mathrm{~Hz}, f_{2}=6,59 \mathrm{~Hz}$, $f_{3}=11,13 \mathrm{~Hz}, f_{4}=17,09 \mathrm{~Hz}$, i $f_{5}=20,23 \mathrm{~Hz}$. 

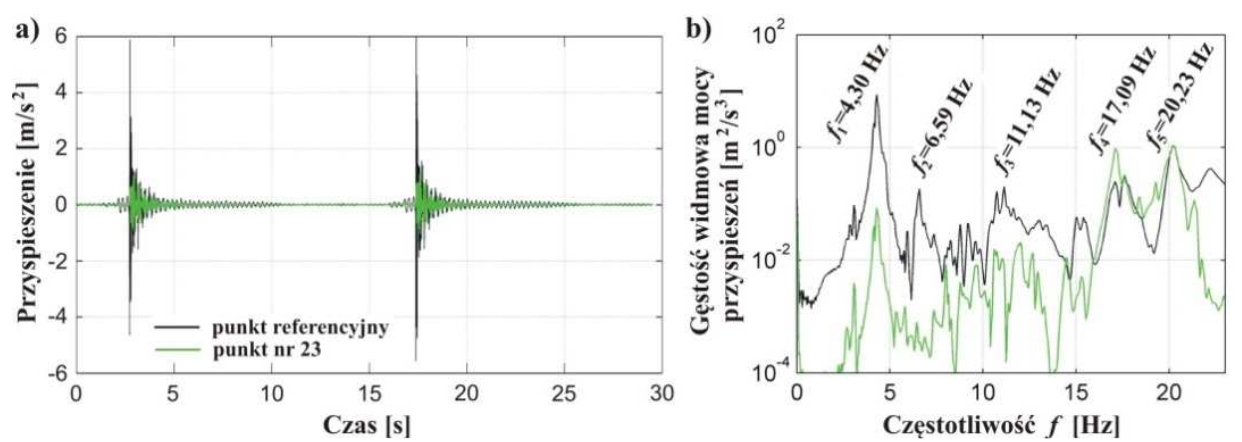

Rys. 5. a) Wyniki pomiarów składowej pionowej przyspieszeń drgań dźwigara „A” kładki w punkcie referencyjnym i w punkcie pomiarowym nr 23 pod wpływem wymuszeń impulsowych oraz b) wykresy funkcji gęstości widmowej mocy zarejestrowanych przyspieszeń

Fig. 5. a) Measurement results of vertical component of footbridge girder "A" acceleration at the reference point and measuring point no 23 due to impulse excitations and (b) the power spectral density functions of the recorded accelerations

\section{Postacie drgań własnych}

W celu wyznaczenia postaci drgań własnych pomostu analizowanej kładki, odpowiadających kolejnym częstościom drgań własnych, zastosowano procedurę metody dekompozycji w dziedzinie częstotliwości, znanej w literaturze światowej pod nazwą Frequency Domain Decomposition (FDD).

Metoda FDD została opracowana przez Brincker'a [1]. Zgodnie z algorytmem metody należy wyznaczyć rozkład według wartości osobliwych (ang. Singular Value Decomposition) zbioru macierzy gęstości widmowych mocy $\mathbf{G}_{x x}\left(\mathrm{i}_{i}\right)$ odpowiedzi konstrukcji zarejestrowanych w co najmniej dwóch punktach pomiarowych jednocześnie. Przykładowo dla przyspieszeń drgań zarejestrowanych jednocześnie $w$ dwóch punktach pomiarowych macierz gęstości widmowych odpowiedzi $\mathbf{G}_{x x}$ dla określonej dyskretnej częstości $f_{i}$ ma następującą postać:

$$
\mathbf{G}_{x x}\left(\mathrm{i} f_{i}\right)=\left[\begin{array}{ll}
P S D_{11}\left(\mathrm{i} f_{i}\right) & C S D_{12}\left(\mathrm{i} f_{i}\right) \\
C S D_{21}\left(\mathrm{i} f_{i}\right) & P S D_{22}\left(\mathrm{i} f_{i}\right)
\end{array}\right]
$$

gdzie: $P S D_{r r}\left(\mathrm{i} f_{i}\right)$ - elementy na głównej przekątnej oznaczające gęstości widmowe odpowiedzi konstrukcji w punkcie pomiarowym $r$, które dla procesów rzeczywistych są zwykłymi rzeczywistymi gęstościami widmowymi składowych procesów $x_{r}(t)$ przedstawiających drgania konstrukcji w punkcie $r$, $C S D_{q r}\left(\mathrm{i} f_{i}\right)$ - wzajemne gęstości widmowe odpowiedzi konstrukcji w różnych jej punktach $q$ i $r$, które są zespolonymi, hermitowskimi gęstościami widmowymi spełniającymi własność $C S D_{q r}\left(\mathrm{i} f_{i}\right)=C S D_{r q}^{*}\left(\mathrm{i} f_{i}\right), \operatorname{przy} \operatorname{czym} q \neq r$, a górny indeks ,", oznacza operator wielkości zespolonej sprzężonej, $\mathrm{i}=\sqrt{-1}-$ jednostka urojona. 
Nie omawiając dalej szczegółów podstaw teoretycznych metody FDD (podstawy te wyjaśnione są w literaturze, np. [1]), należy podkreślić, że każdą macierz $\mathbf{G}_{x x}\left(\mathrm{i} f_{i}\right)$ dla określonej dyskretnej częstości $f_{i}$ można przedstawić w postaci rozkładu według wartości osobliwych jako iloczyn macierzy diagonalnej $\mathbf{S}_{i}$ i macierzy unitarnej $\mathbf{U}_{i}$ w następującej postaci:

$$
\mathbf{G}_{x x}\left(\mathrm{i} f_{i}\right)=\mathbf{U}_{i} \mathbf{S}_{i} \mathbf{U}_{i}^{H}
$$

gdzie: $\mathbf{S}_{i}=\operatorname{diag}\left[s_{1}\left(f_{i}\right), s_{2}\left(f_{i}\right), \ldots, s_{j}\left(f_{i}\right), \ldots, s_{n}\left(f_{i}\right)\right]-$ macierz diagonalna, odpowiadająca $i$-tej dyskretnej częstości $f_{i}$, zawierająca zbiór dyskretnych wartości osobliwych $s_{j}\left(f_{i}\right)$,

$\mathrm{U}_{i}=\left[\left\{u_{i 1}\right\},\left\{u_{i 2}\right\}, \ldots,\left\{u_{i j}\right\}, \ldots,\left\{u_{i n}\right\}\right]-$ macierz unitarna zawierająca kolumnowe wektory osobliwe $\left\{u_{i j}\right\}$, odpowiadające $i$-tej dyskretnej częstości $f_{i}, j=$ $=1,2, \ldots, n$,

$n$ - wymiar macierzy $\mathbf{G}_{x x}\left(\mathrm{i} f_{i}\right)$, wynikający z liczby punktów pomiarowych, w których zarejestrowano sygnały cyfrowe przedstawiające odpowiedź badanej konstrukcji.

Wykres pierwszych wartości osobliwych $s_{1}\left(f_{i}\right)$ w dziedzinie częstotliwości jest zdominowany przez wartości maksymalne, które na osi odciętych odpowiadają kolejnym częstościom drgań własnych badanej konstrukcji $f_{0 k}$. Z kolei pierwsze wektory osobliwe $\left\{u_{i 1}\right\}$ macierzy $\mathbf{U}_{i}$, odpowiadające maksymalnym wartościom osobliwym $s_{1}\left(f_{0 k}\right)$, określają bezwymiarowe rzędne $k$-tej postaci drgań własnych odpowiadającej częstości drgań własnych $f_{0 k}$, stąd:

$$
\phi_{k}=\left\{u_{k 1}\right\} .
$$

Postacie drgań własnych analizowanej kładki wyznaczono na podstawie wyników pomiarów przyspieszeń pionowych drgań swobodnych jej pomostu, wymuszonych pojedynczymi podskokami jednej osoby, zarejestrowanych jednocześnie $\mathrm{w}$ dwóch różnych punktach pomiarowych, tj. w stałym punkcie referencyjnym i w punktach pomiarowych od 1 do 27 . Obliczenia wykonano za pomocą autorskiego programu komputerowego, napisanego w środowisku MATLAB. Gęstości widmowe PSD i CSD dyskretnego sygnału cyfrowego, przedstawiającego drgania swobodne analizowanej kładki, wyznaczono techniką Welcha [8]. Na rysunku 6. przedstawiono wykresy funkcji wartości osobliwych $s_{1}(f)$ i $s_{2}(f)$ gęstości widmowej mocy zarejestrowanych przyspieszeń drgań swobodnych dźwigara „A" w punkcie referencyjnym i w punkcie pomiarowym nr 23 i wyznaczone metodą FDD częstości drgań własnych kładki od $f_{01}$ do $f_{05}$. Wartości rzędnych pięciu pierwszych postaci drgań własnych pomostu analizowanej kładki i ich teoretyczną aproksymację przedstawiono na rys. 7. 


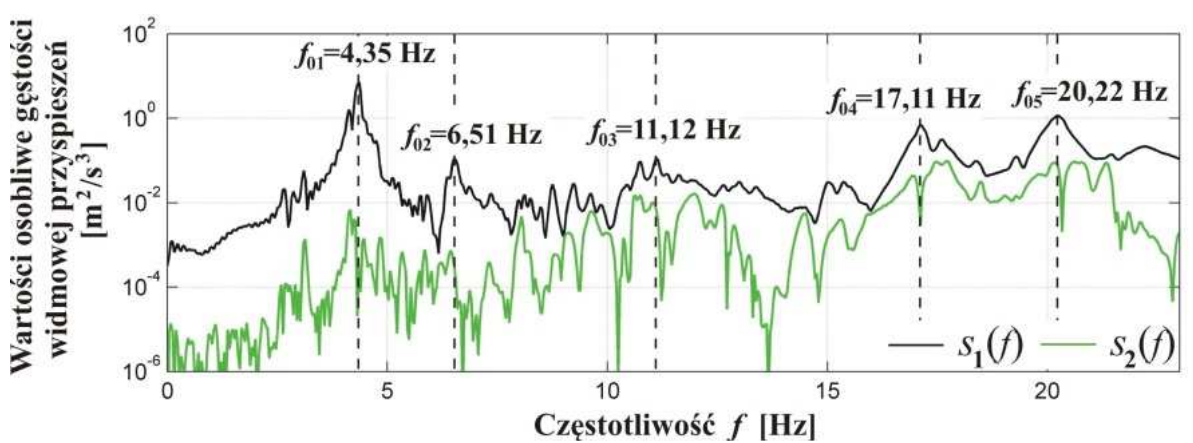

Rys. 6. Funkcje wartości osobliwych na podstawie zarejestrowanych przyspieszeń pionowych drgań swobodnych dźwigara kładki w punkcie referencyjnym i w punkcie pomiarowym nr 23

Fig. 6. Singular values functions based on the recorded vertical free vibrations of the footbridge girder at the reference point and measuring point no 23

\section{Liczba tłumienia konstrukcyjnego}

Wartości liczby tłumienia konstrukcyjnego $\xi_{k}$ pomostu analizowanej kładki, odpowiadające częstościom drgań własnych $f_{0 k}$, zostały obliczone na podstawie zarejestrowanych przyspieszeń pionowych drgań swobodnych pomostu w punkcie referencyjnym. W tym celu dokonano dekompozycji zarejestrowanych przyspieszeń drgań na pięć składowych drgań swobodnych charakteryzujących się analizowanymi częstościami drgań od $f_{01}$ do $f_{05}$. Dekompozycji drgań dokonano techniką filtracji $\mathrm{z}$ zastosowaniem filtru Chebysheva typ 1, pasmowoprzepustowego, rzędu 8, ze współczynnikiem zafalowań $1 \mathrm{~dB}$. Procedurę filtracji wykonano przyjmując pasma częstości przepustowych znajdujących się w następujących przedziałach: 3,5-5,0 Hz; 6,0-6,8 Hz; 11,0-11,5 Hz; 16,8-17,3 Hz i 19,5-20,7 Hz. Przykład zastosowania podobnej procedury dekompozycji drgań w celu wyznaczenia thumienia konstrukcji przedstawiono w pracy [8].

Wartości liczby tłumienia konstrukcyjnego $\xi_{k}$ wyznaczono za pomocą aproksymacji odfiltrowanych przyspieszeń drgań swobodnych dźwigara kładki $q_{k}(t)$ metodą najmniejszych kwadratów za zastosowaniem funkcji aproksymującej $a_{k}(t)$ ze względu na niewiadome $\omega_{0 k}, \xi_{k}, x_{0 \mathrm{k}} i \varphi_{k} \mathrm{~W}$ następujący sposób:

$$
q_{k}(t)=a_{k}(t)+m_{k}(t)=\frac{x_{0 k}}{\sqrt{1-\xi_{k}^{2}}} e^{-\xi_{k} \omega_{0 k} t} \cos \left(\sqrt{1-\xi_{k}^{2}} \omega_{0 k} t-\varphi_{k}\right)+m_{k}(t)
$$

gdzie: $\omega_{0 k}=2 \pi f_{0 k}-$ częstość kołowa drgań własnych,

$x_{0 k}$ - wartość początkowa,

$\varphi_{k}$ - faza początkowa,

$m_{k}(t)=q_{k}(t)-a_{k}(t)-$ funkcja błędu aproksymacji. 

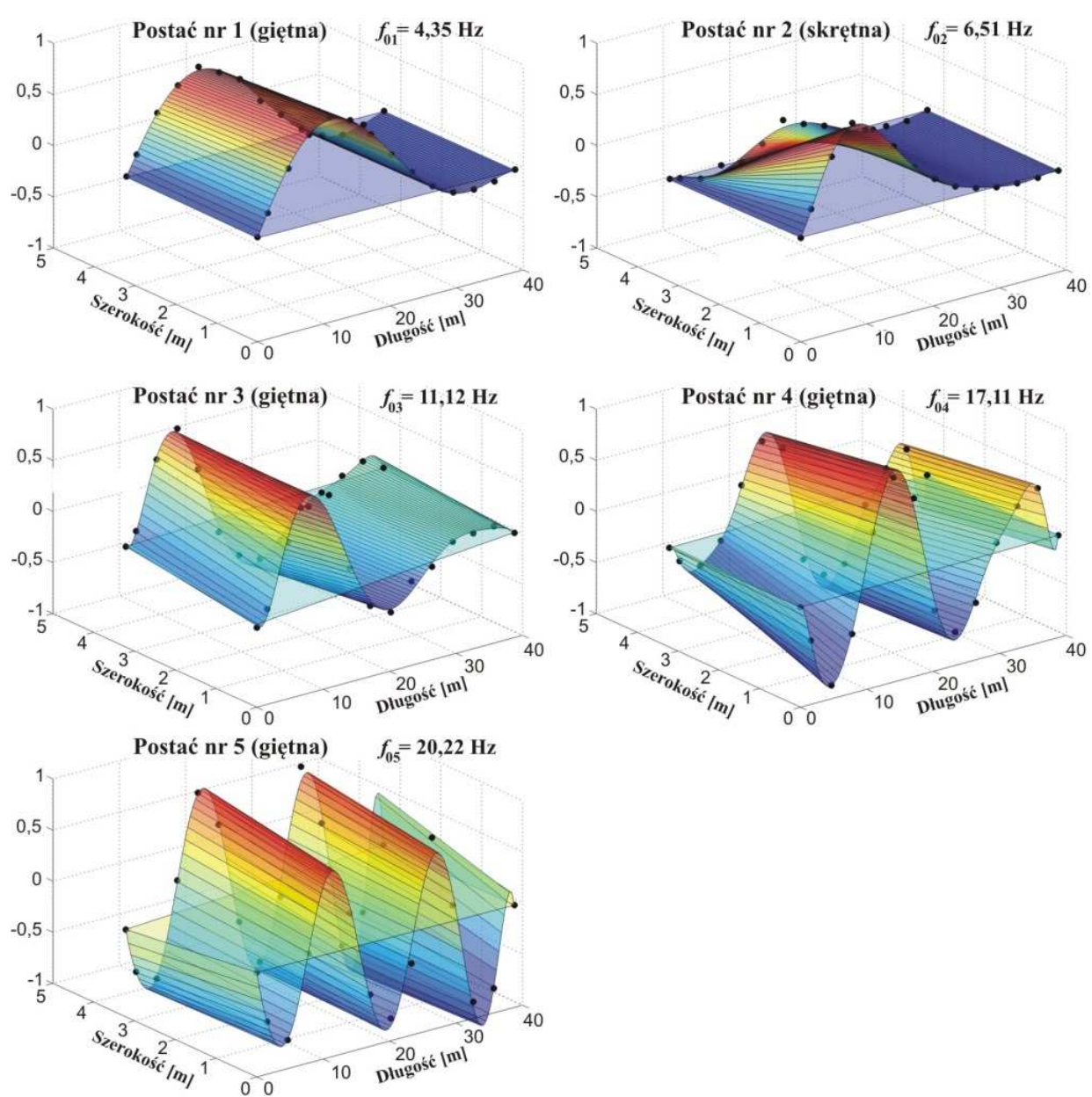

Rys. 7. Teoretyczna aproksymacja rzędnych postaci drgań własnych pomostu analizowanej kładki dla pieszych wyznaczonych na podstawie pomiarów doświadczalnych

Fig. 7. Theoretical approximation of mode shapes ordinates of the analyzed footbridge deck determined using measurement data

Na rysunku 8. przedstawiono wyniki obliczeń wartości liczby tłumienia $\xi_{k}$ odpowiadające pięciu pierwszym częstościom drgań własnych $f_{0 k}$ pomostu analizowanej kładki. Przedstawiono tu także wykresy: odfiltrowanych przyspieszeń drgań swobodnych dźwigara kładki $q_{k}(t)$, funkcji aproksymującej $a_{k}(t)$ i funkcji błędu aproksymacji $m_{k}(t)$. 

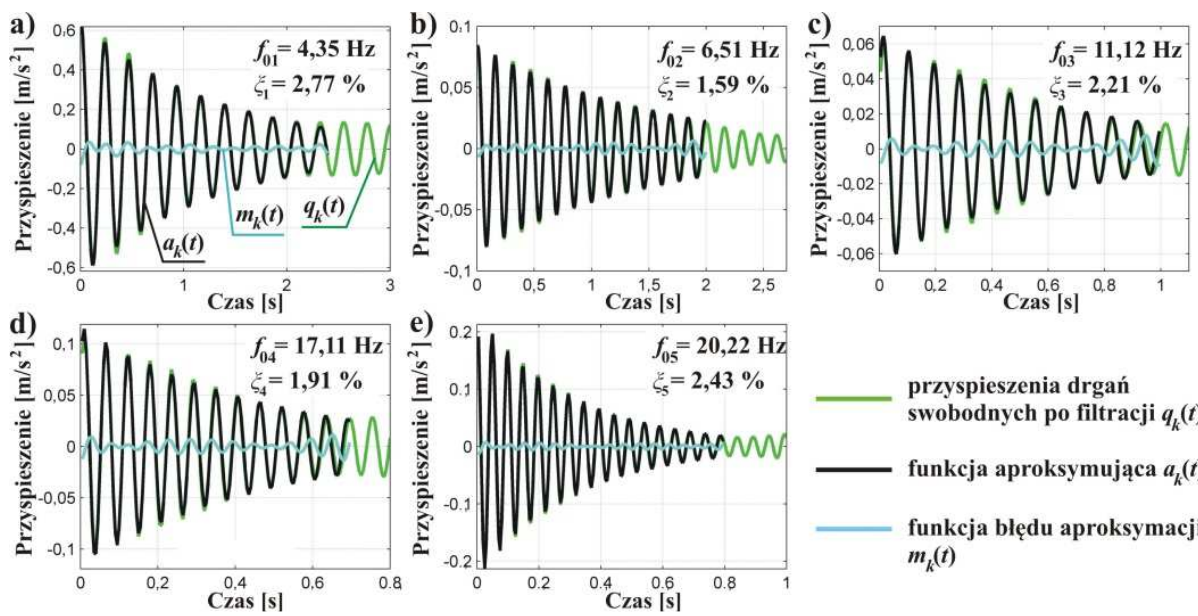

przyspieszenia droań swobodnych po filtracji $q_{k}(t)$

funkcja aproksymująca $a_{k}(t)$

funkcja blędu aproksymacji $m_{k}(t)$

Rys. 8. a) Teoretyczna aproksymacja przyspieszeń drgań swobodnych dźwigara kładki po filtracji z zastosowaniem filtru Chebysheva typ 1, rzędu 8, pasmowo-przepustowego dla częstości w przedziale: a) $3,5-5,0 \mathrm{~Hz}$, b) $6,0-6,8 \mathrm{~Hz}$, c) $11,0-11,5 \mathrm{~Hz}$, d) $16,8-17,3 \mathrm{~Hz}$ i e) $19,5-20,7 \mathrm{~Hz}$

Fig. 8. Theoretical approximation of free vibration accelerations of footbridge girder after filtering using the eighth-order Type 1 Chebyshev band-pass digital filter with pass-band: a) 3.5-5.0 Hz, b) $6.0-6.8 \mathrm{~Hz}$, c) $11.0-11.5 \mathrm{~Hz}$, d) $16.8-17.3 \mathrm{~Hz}$ and e) $19.5-20.7 \mathrm{~Hz}$

\section{Wzajemne porównanie liczby tłumienia wybranych kładek}

Na rysunku 9. przedstawiono wzajemne porównanie wartości liczby tłumienia konstrukcyjnego wyznaczone doświadczalnie dla analizowanej kładki wykonanej w całości z kompozytu GFRP i wybranych kładek dla pieszych wykonanych $\mathrm{z}$ betonu lub stali o porównywalnych rozpiętościach $\mathrm{w}$ odniesieniu do ich częstości drgań własnych (dane zaczerpnięto z literatury [2-3]).

\section{Podsumowanie}

W pracy przedstawiono wyniki identyfikacji pięciu pierwszych częstości drgań własnych, odpowiadających im postaci drgań własnych i wartości liczby tłumienia konstrukcyjnego podwieszonej kładki dla pieszych wykonanej w całości z kompozytu polimerowego na bazie włókien szklanych GFRP. Postacie drgań własnych nr 1, 3, 4 i 5 reprezentują formy drgań giętnych pomostu, zaś postać nr 2 jest skrętną formą drgań.

Na podstawie porównania otrzymanych wartości liczby tłumienia analizowanej kładki i wartości literaturowych dla wybranych kładek dla pieszych wykonanych $\mathrm{z}$ betonu lub stali o porównywalnych rozpiętościach (por. rys. 9) stwierdzono, że tłumienie konstrukcyjne kładki wykonanej w całości z kompozytu GFRP jest największe i mieści się w przedziale od 1,6 do 2,8 \% dla wszystkich analizowanych częstości drgań własnych. Tłumienie kładek betonowych mieści się w przedziale od 0,2 do $1,8 \%$, zaś stalowych od $0,2-2,1 \%$. 


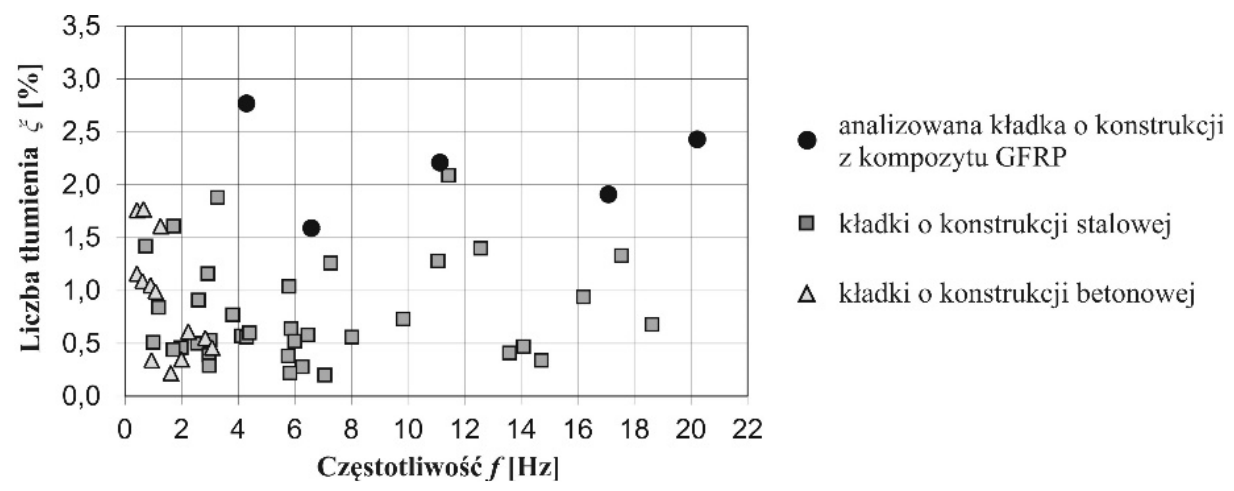

Rys. 9. Wzajemne porównanie doświadczalnych wartości liczby tłumienia analizowanej kładki z kompozytu GFRP i wybranych kładek dla pieszych wykonanych z innych materiałów w odniesieniu do ich częstości drgań własnych (na podstawie danych literaturowych [2-3])

Fig. 9. Comparison of measured damping ratios of the analysed footbridge made of GFRP composite and selected footbridges made of various materials regarding them natural vibration frequency (based on literature data [2-3])

Ze względu na niewystarczającą liczbę publikacji dotyczących badań charakterystyk dynamicznych i odpowiedzi pod obciążeniem dynamicznym obiektów mostowych o konstrukcji wykonanej z kompozytów polimerowych GFRP obecnie istnieje duża potrzeba wykonania takich badań. Informacje uzyskane z tych badań mogą być pomocne na etapie projektowania tego typu nowych obiektów w celu weryfikacji przyjętych dla nich modeli obliczeniowych i przewidywania ich odpowiedzi pod obciążeniem dynamicznym, a także w celu oceny i monitorowania stanu technicznego istniejących obiektów.

\section{Literatura}

[1] Brincker R., Zhang L., Andersen P.: Modal identification from ambient responses using frequency domain decomposition. ,Proc. of the $18^{\text {th }}$ International Modal Analysis Conference (IMAC)", Kissimmee, USA, 2000.

[2] Brownjohn J.M.W., et al.: Footbridge system identification using wireless inertial measurement units for force and response measurements, Journal of Sound and Vibration, vol. 384, 2016, s. 339-355.

[3] Butz C., et al.: Advanced load models for synchronous pedestrian excitation and optimised design guidelines for steel footbridges (SYNPEX), Final Report, RFCS, 2007.

[4] Cortright S.R.: Bridging the World, Bridge INK, Wilsonville, 2003.

[5] Fiberline Composites, https://fiberline.com/fiberline-bridge-kolding (dostęp: 1 marca 2017 r.).

[6] Kutz M.: Construction applications of composites. In: Kutz M., editor. Handbook of materials selection. John Wiley\& Sons; 2002, s. 1415.

[7] Li Y.F., Badjie S., W. Chen W., Chiu Y.T.: Case study of first all-GFRP pedestrian bridge in Taiwan, Case Studies in Construction Materials, vol. 1, 2014, s. 83-95. 
[8] Magalhăes F., Cunha Á., Caetano E., Brincker R.: Damping estimation using free decays and ambient vibration tests, Mechanical Systems and Signal Processing, vol. 24, 2010, s. 1274-1290.

[9] Miśkiewicz M., Pyrzowski Ł., Rucka M., Wilde K., Klasztorny M., Chróścielewski J.: Kompozytowy most pieszo-rowerowy w kampusie Politechniki Gdańskiej badania doświadczalne, Wydawnictwa Uczelniane Uniwersytetu TechnologicznoPrzyrodniczego, Bydgoszcz 2015, s. 265-272.

[10] Skinner J.M.: A critical analysis of the Aberfeldy Footbridge, Scotland, Proceedings of Bridge Engineering $2^{\text {nd }}$ Conference, University of Bath, Bath, UK, 2009.

[11] Stankiewicz B.: Composite GFRP deck for bridge structures, Procedia Engineering, vol. 40, 2012, s. 423-427.

[12] Stankiewicz B.: Durability of glass fiber-reinforced polymer bridge panel based on differential thermal analysis, dynamic mechanical analysis, and differential scanning calorimetry analysis, Journal of Composite Materials, doi: 10.1177/0021998316669857 (publikacja w druku).

\section{INVESTIGATION OF DYNAMIC CHARACTERISTICS OF CABLE- STAYED FOOTBRIDGE MADE OF GFRP COMPOSITE}

\section{S u m m a r y}

The aim of this paper is to investigate of dynamic characteristics of cable-stayed footbridge in Kolding, Denmark, made entirely of Glass Fiber Reinforced Polymer (GFRP) composite. During examination based on in situ free-decay measurements and using accelerometers under human jumping the primary five natural frequencies, corresponding mode shapes and damping ratios of the footbridge were identified. The Frequency Domain Decomposition (FDD) approach was applied to identify the natural frequencies and mode shapes. The corresponding damping ratios were extracted by using a least square curve fitting approximation of the filtered free-decay vibration of the footbridge deck. The estimated damping ratios were compared with data published in the literature for selected footbridges made of various conventional materials. The obtained experimental results provide a relevant data regarding the dynamic response prediction or structural health monitoring of all-GFRP composite footbridges.

Keywords: bridge structure, GFRP composite, modal parameters, free-decay vibration, structural damping

Przestano do redakcji: 23.06 .2017 r.

Przyjęto do druku: 01.09.2017 r. 